\title{
POPULATION CHARACTERISTICS OF THE HOUSE RAT (RATTUS RATTUS) IN RURAL AREAS OF POTHWAR, PAKISTAN
}

\author{
Surrya Khanam*a, b and Muhammad Mushtaq ${ }^{b}$ \\ aDepartment of Zoology, Women University Swabi, Swabi 23430, Pakistan \\ ${ }^{b}$ Department of Zoology, PMAS Arid Agriculture University, Rawalpindi, Pakistan \\ Corresponding author. Email: Surryiamalik@gmail.com
}

\section{Article history \\ Received: 30 June 2021; \\ accepted: 15 October 2021}

\section{Keywords:}

House rat; commensal rodents; pests, ecology; villages; population characteristics

\begin{abstract}
The house rat (Rattus rattus) is the major commensal rodent species present in rural habitats of Pakistan. Little is known about the biology of this species in the country. Hence, proper control plans for its management could not be developed. The objective of the present study was to determine the population biology of the house rat in rural commensal habitats of Pothwar, Pakistan. A two-year study was conducted in four villages during four seasons. A total of 217 house rats were captured with snap traps. The species had an unbiased sex ratio. Individuals from different age groups were present in the population, and the adults outnumbered sub-adults and juveniles. Reproductive activity was observed throughout the year, and reproductively active individuals outnumbered the inactive ones. These results show that rural commensal habitats were providing suitable environment for the house rats throughout the year. The findings of the present study will be useful for the planning of control strategies in the commensal habitats of rural Pothwar.
\end{abstract}

\section{INTRODUCTION}

The house rat (Rattus rattus) is an important pest with a worldwide distribution. The species originated in the Indian subcontinent and spread throughout the world due to different human activates and international trade (Etougbétché et al. 2020). This species is present in different types of habitats ranging from commensal (Sridhara and Krishnamurthy 1992) to non-commensal (Jones et al. 2008; Efford et al. 2006). As a pest species, house rat causes both pre-harvest and post-harvest crop losses, consumes and contaminates different food items, and damages buildings (Duplantier et al. 2003; Pimentel et al. 2005; Meerburg et al. 2009). Also, the house rat is considered an important host for different types of pathogens, including zoonotic bacteria, viruses, and parasites, and therefore poses a serious risk to public health (Himsworth et al. 2013).

The population characteristics of species vary according to the environmental conditions or geography of a particular area. Therefore, for implementation of an effective pest management plan in a particular area, deep understanding of the biology of the involved species is crucial. Along with the development of management plans for pest control, ecological studies of pest species can help to understand the species pathogenic status (Volkova et al. 2010; Byers et al. 2019).

Previously, the biology of house rat has been studied in different types of habitats ranging from commensal to natural forests systems (Sridhara and Krishnamurthy 1992; Dowding and Murphy1994; Panti-May et al.
2012; Shiels et al. 2013). In Pakistan, although this rodent species is present throughout the country, the information on its biology is scarce and limited to a single study from south Punjab (Mushtaq-ul-Hassan 1993), and no such information is available from the proposed study area. The proposed study area, Pothwar, is located in the rain-fed region of the country and has a significant contribution to the agriculture sector of Pakistan. The majority of the rural human population depends on agriculture for their livelihood. Currently, farmers are experiencing grain losses in their storages due to indoor rodent species (Khanam and Mushtaq 2021), and the house rat has been reported as the second most abundant species in the indoor conditions of Pothwar (Khanam et al. 2017). The aim of this study was to describe the following population characteristics: abundance, sex ratio, age structure and reproductive characteristics of house rats from rural habitats of Pothwar, Pakistan. The findings of this work would be helpful to develop an effective management plan for the control of this species in the rural indoor habitats and minimizing post-harvest losses.

\section{MATERIALS AND METHODS}

\section{Study area}

This study was conducted in Pothwar $\left(32.5^{\circ} \mathrm{N}-34.0^{\circ} \mathrm{N}\right.$ and $72^{\circ} \mathrm{E}-74^{\circ} \mathrm{E}$ ), northern Punjab, Pakistan. It is a rainfed area, comprising four districts of Punjab (Attock, Chakwal, Jehlum, and Rawalpindi) and Islamabad capi- 
tal territory (ICT). The area is located at an elevation of 350 to $575 \mathrm{~m}$ above the sea level with the undulating topography generally sloping from northeast to southwest. The region is characterized by semi-arid to humid climate with the annual rainfall of the area ranges from $450 \mathrm{~mm}$ in the southwest to $1750 \mathrm{~mm}$ in northeast, and $70 \%$ rainfall occurring during the monsoon months of July to September (Tariq 2004; Rashid and Rasul 2011). Arid agriculture is practiced in Pothwar, and about 1 Mha of the total 2.2 Mha area is used for several agricultural activities. Wheat is the major winter crop (November-May) and ground nuts and millet are the major summer crops in the region (May-October).

\section{Animal trapping}

We conducted rodent seasonal trapping in four villages of Pothwar: Kisran (site I), Makhial (site II), Ahmedabad (site III), and Usmanzada Adra (site IV) from March 2012 to February 2014 (Figure 1). In each village, we installed metallic snap traps of two sizes $(17 \times 9.5 \mathrm{~cm}$ and $11.5 \times 4.5 \mathrm{~cm}$ ) in three types of buildings: households $(\mathrm{N}=6), \mathrm{b})$ shops $(\mathrm{N}=3)$, and $\mathrm{c})$ farm houses $(\mathrm{N}=1)$. A household refers to a residence within the main village. Village shops refer to small general stores which sell different type of food items, daily used products, fruits, and vegetables. A farm house refers to a rural residence build away from the main village, where the villagers keep their animals and perform different agricultural activities. In each trapping session, sixty traps (6 traps in each structure) were set per night for four consecutive nights. During the two-year trapping, a total of 320 structures (192 households, 96 shops and 32 farm houses) were sampled for rodents. Traps baited with bread (roti) soaked in vegetable oil were set in the evening $(6 \mathrm{pm}-7 \mathrm{pm})$ and checked in the next morning ( $6 \mathrm{am}-8 \mathrm{am})$. Each trapped animal was identified and assigned a field number, capture date, capture location and was put in plastic bags before being carried to the laboratory.

\section{Estimation of population characters}

In the laboratory, each animal was inspected for sex, weight and standard body measurements (including head-body length, tail length, hind foot and ear length). Based on the body weight, individuals were classified into three age classes (juveniles, sub-adults and adults). The juvenile class included females weighing $<30 \mathrm{~g}$ and males $<35 \mathrm{~g}$. The sub-adult female rats weighed between $30-70 \mathrm{~g}$ and the sub-adult males weighed between $35-80 \mathrm{~g}$. The adult females and males weighed $>70 \mathrm{~g}$ and $>80$ g, respectively (Panti-May et al. 2012).

To assess the reproduction patterns, external and internal reproductive characteristics of both male and female individuals were registered. Males with scrotal testes were considered reproductively active and with abdominal testes were considered inactive. Also, we registered weight, length, width and volume of testes and calculated their volume using the formula of an ellipsoid: $\mathrm{V}=\mathrm{ab}^{2}$, where " $\mathrm{a}$ " is half the maximum length and " $b$ " is half the maximum width (Woodall and Skinner 1989).

In females, the external condition of the vagina, either perforated or non-perforated was noted. Also, pregnancy, the number of embryos and the number of scars were registered. Following Aplin et al. (2003), uterine horns were classified into the following categories: 1) juvenile females: uterine horns very thin, short with

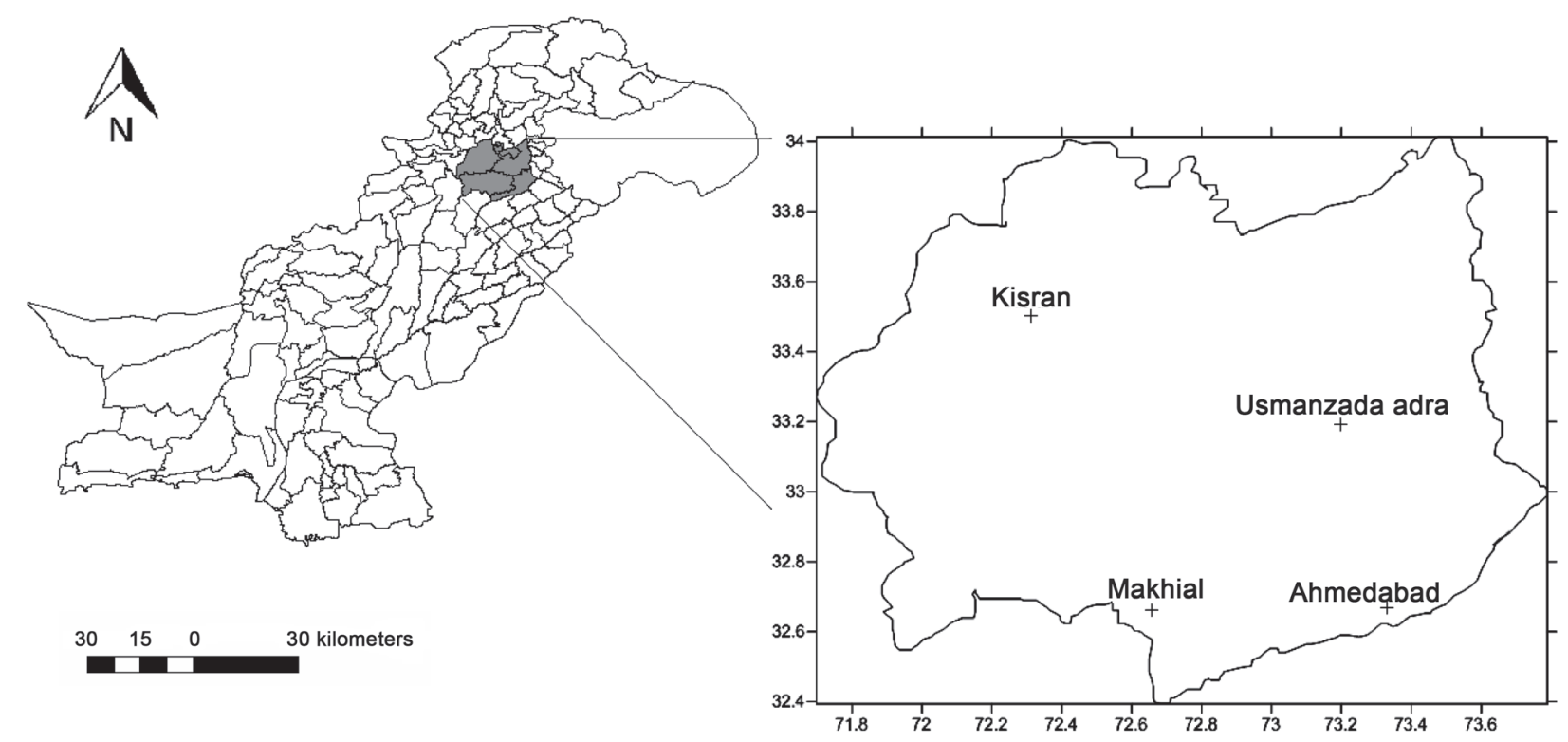

Figure 1. Map of Pakistan showing location of Pothwar region. In focus are the four study villages in their respective districts. 
reduced blood supply, vagina either imperforate or recently opened, 2) females entering first breeding season: uterine horns slightly thicker with apparent blood supply, but no embryo or placental scars, 3) pregnant females: uterine horns thicker with the embryo present in one or both horns, indicating pregnancy in the female, 4) post-partum females: uterine horns elongated and thin-walled without embryos, but with visible placental scars, and 5) females ready to conceive: uterine horns elongated, thick-walled with visible placental scars but no embryos, horns are compact after a few days of delivery. All those females that were pregnant, lactating, had placental scars in their uteri, or were entering the first breeding were considered reproducing females.

\section{Statistical analysis}

The Chi-square goodness of fit test was used to check the deviation from 1:1 sex ratio (male : female) at each site and during each season. The Chi-square test of homogeneity was used to check for difference in sex ratio and age structure across sites and seasons. The Kruskal-Wallis test was used to check for variation in testicular measurements (i.e. testes weight, length, width and volume) across different trapping seasons. Variations in the number of embryos and the number of placental scars across sites and seasons were compared using the Kruskal-Wallis test. All differences with $p>$ 0.05 were considered non-significant. All the analyses were performed using the statistical package for social sciences (SPSS) software (version 16.0).

\section{RESULTS}

A total of 217 specimens of house rat were captured from three of the four studied sites: site I $(n=50)$, site III $(\mathrm{n}=134)$ and site IV $(\mathrm{n}=33)$. At site II, no house rat individual was captured during all trapping sessions. Along with the house rat, eight other species of small mammals were captured in the two-year study. The species included: Mus musculus $(\mathrm{n}=436)$, Suncus murinus (54), Tatera indica (20), Millardia meltada (9), Golunda ellioti (7), Bandicota bengalensis (1), Nesokia indica (1), and Mus booduga (1). Of 217 house rat samples, 196 could be used because 21 of them were decayed and were not autopsied.

\section{Sex ratio}

In Table 1 there is given the proportion of two sexes in three age classes of the house rat. Taking into account the total of analyzed house rats $(\mathrm{N}=196)$, sex ratios were significantly different $\left(\chi^{2}=4.5, \mathrm{df}=1, p=0.03\right.$, $\mathrm{n}=196)$. In each site, sex ratio did not differ significantly from 1:1 $(p>0.05)$. At site I, male to female sex ratio was $0.77: 1(21: 27)$, and at sites III and IV it was $0.72: 1$ (53:73) and 0.69:1 (9:13), respectively.

Although more females than males were captured in all the seasons, sex ratio did not differ significantly from $1: 1(p>0.05)$. Sex ratio was 0.72:1 (21:29) in spring, $0.74: 1$ (17:23) in summer, 0.65:1 (21:32) in autumn, and 0.82:1 (24:29) in winter. Overall, more female individuals than male individuals were present in all the seasons, but statistically sex ratio did not differ significantly from the $1: 1$ ratio in all the seasons.

\section{Age structure}

In Table 1 there are given the proportions of juveniles, sub-adults and adult rats in the pooled samples from the three studied sites. The proportions of the three age categories by season are shown in Figure 2. The proportions of the three age classes in spring and summer were similar, adult rats outnumbered juveniles and sub-adults. In autumn and winter, the proportions of juveniles and sub-adults were higher than that of adults. A significant variation was found in the proportions of individuals in each age class between seasons $\left(\chi^{2}=\right.$ $22.9, \mathrm{df}=3, p=0.00$; Figure 2). The rat populations in spring and summer seasons were structurally different from those in autumn $\left(\chi^{2}=8.8, \mathrm{df}=1, p=0.01, \chi^{2}=7.8\right.$,

Table 1. Age classes and sex ratio in the pooled data of $R$. rattus of the three sites studied in Pothwar. Proportions of the three age classes, regardless of sex, are shown in the last column.

\begin{tabular}{|l|c|c|c|}
\hline $\begin{array}{c}\text { Age } \\
\text { categories }\end{array}$ & $\begin{array}{c}\text { Males } \\
\%(n)\end{array}$ & $\begin{array}{c}\text { Females } \\
\%(n)\end{array}$ & $\begin{array}{c}\text { Sexes combined } \\
\%(n)\end{array}$ \\
\hline Juvenile & $42(14)$ & $58(19)$ & $16.8(33)$ \\
\hline Sub-adult & $43(24)$ & $57(32)$ & $28.6(56)$ \\
\hline Adult & $42(45)$ & $58(62)$ & $54.6(107)$ \\
\hline Total & $42(83)$ & $58(113)$ & $100(196)$ \\
\hline
\end{tabular}

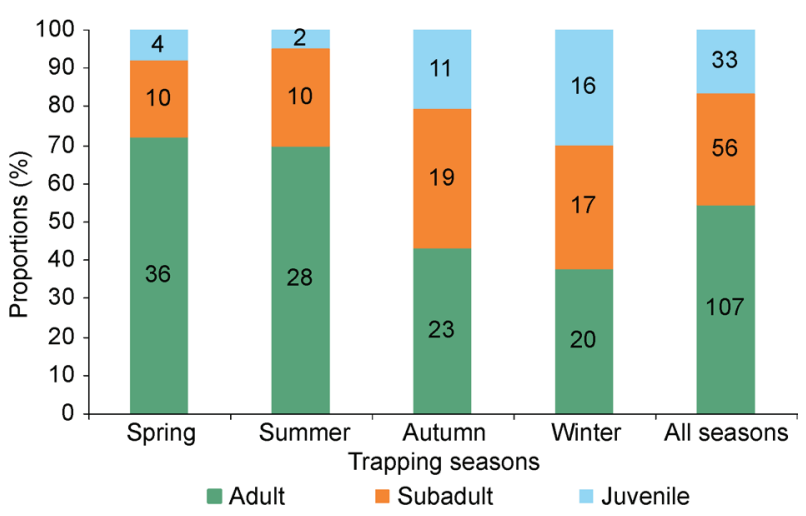

Figure 2. Age structure of the $R$. rattus population in rural Pothwar in four seasons of the year. Percentages are based on the number of individuals of each age class as shown within the bars. 
$\mathrm{df}=12, p=0.02$, respectively $)$ and winter $\left(\chi^{2}=13.5, \mathrm{df}\right.$ $=1, p=0.00, \chi^{2}=12.4, \mathrm{df}=1, p=0.00$, respectively) seasons.

\section{Reproduction}

The proportions of reproductively active males were $100 \%, 73 \%, 100 \%$, and $96 \%$, in spring, summer, autumn, and winter seasons, respectively. There was no seasonal difference found in the various testicular measurements (i-e testes weight, length, width and volume) of adult rats ( $p>0.05$ for all measurements). The mean testes weight was $726 \pm 34 \mathrm{mg}($ range $=400-1310)$, mean testes length was $14.3 \pm 0.5 \mathrm{~mm}$ (range $=5-22)$, mean testes width was $7.9 \mathrm{~mm} \pm 0.3 \mathrm{~mm}$ (range $=$ $4.5-10.5)$, and mean testes volume was $289 \pm 25.3 \mathrm{~mm}^{3}$ (range $=47.7-52.3$ )

In male rats, no significant variations were present in the proportion of reproductive individuals at the three sites $(p>0.05)$. Reproductively active males numerically predominated at all the three sites. At site I, 75\% $(\mathrm{n}=9)$ of adult rats had scrotal testes, and 96\% $(\mathrm{n}=$ $25)$ and $86 \%(\mathrm{n}=8)$ had scrotal testes at sites III and IV, respectively.

A total of 62 adult females were captured from all the three study sites. In all, 23 of 62 adult females (i.e. $37 \%$ ) were pregnant (Figure 3). The proportion of pregnant females at site I was $28 \%$, while at sites III and IV the proportion was $40 \%$ and $44 \%$, respectively. The proportion of females carrying placental scars was $28 \%, 31 \%$, and $22 \%$ at sites I, III, and IV, respectively; overall, the proportion of females with placental scars was $29 \%$ (Figure 3 ). The proportion of females entering first breeding was $44.4 \%, 28.6 \%$, and $33.3 \%$ at sites I, III, and IV, respectively.

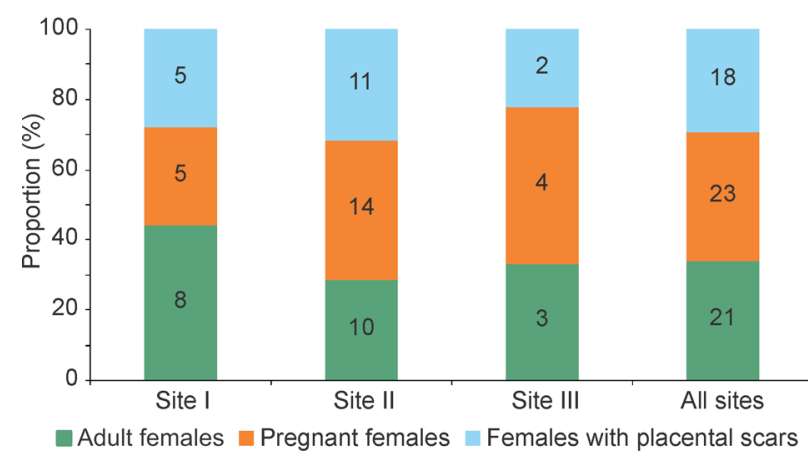

Figure 3. Proportion of $R$. rattus females in different reproductive states at different trapping sites. Percentages are based on the number of females indicated within the bars.

The proportion of pregnant females in spring was $45 \%$, while in summer, autumn and winter the proportion was $24 \%, 38 \%$, and 40\%, respectively (Figure 4 ). Across all the sites, the number of embryos in the litter ranged from 4 to 11 with the mean litter size of $6.9 \pm 1.9$ (Mean \pm
SD). Eighteen of the female rats had placental scars on their uteri. In these females, the number of scars ranged from 4-16 with a mean of $9.3 \pm 3.1($ Mean \pm SD), and 9 and 11 scars were the most frequently found numbers of scars in females.

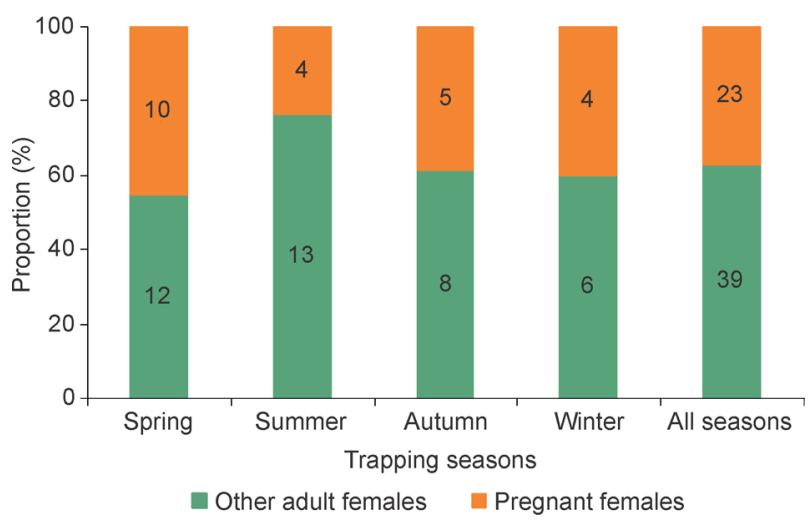

Figure 4. Proportion of pregnant $R$. rattus in different seasons. Percentages are based on the number of females indicated within the bars.

\section{DISCUSSION}

In the present study, the sex ratio of the house rat did not deviate significantly from 1:1 at individual sites. However, the merged data of all the sites showed a female-biased ratio in the rat population. Other studies have reported female-biased (Brooks et al. 1978; Sridhara and Krishnamurthy 1992), male-biased (Muhstaq et al. 2014), as well as unbiased (Brooks et al. 1994; Miller and Miller 1995; Efford et al. 2006; Panti-May et al. 2012) sex ratios in $R$. rattus populations. According to Wright et al. (1988), in polygamous species, the sex ratio of $1: 1$ is expected when there is plenty of food in the habitat. In the rural commensal habitat, abundant food resources were available to the rats round the year. Therefore, it might be possible that two sexes were not competing with each other for food; hence, there was no disparity in the number of two sexes at individual sites.

In this study, adult individuals outnumbered sub-adult and juvenile individuals. From India, Sridhara and Krishnamurthy (1992) reported that in a $R$. rattus population infesting the poultry farms, adults had numerical superiority over sub-adult and juvenile rats. Also, the capture of more adult individuals has been previously reported in other commensal species (Gomez et al. 2008), and the possible reasons for such trend could be mortality of juvenile individuals or dispersal of nonadult individuals (King 1982).

As in previous studies (Sridhara and Krishnamurthy 1992; Brooks et al. 1994; Panti-May et al. 2012), we observed that rats reproduce throughout the year. The 
litter size of house rats in the present study was $6.5 \pm 1.9$ (SD). This is well in the range reported in other studies. For instance, Mushtaq-ul-Hassan (1993) reported a litter size of 6.9 for the rat population of rural Faisalabad, Punjab. While Beg et al. (1983) reported a litter size of 6.2 for the rat populations of urban Faisalabad. Sridhara and Krishnamurthy (1992) recorded a litter size of 5.6 in the rat population of Banglore, India. Brooks et al. (1978) reported a litter size of 5.3 in the rat population of Rangoon, Myanmar (formerly Burma), and Panti-May et al. (2012) recorded a litter size of 5.3 embryos for the rat populations present in rural dwellings of Yucatan, Mexico. The possibility of nearly similar litter size in previous studies and in our study could be due to the nature of indoor habitats, as the indoor/commensal conditions usually provide a stable environment with good food and shelter for rodent species to reproduce.

In conclusion, the house rat population of the present study had an apparently unbiased sex ratio. In the trapped samples, adults outnumbered sub-adults and juveniles. The year-round breeding activity was recorded in the commensal rat population, and reproductively active individuals were relatively larger in numbers than inactive individuals. This study generated useful information on the population biology of this important pest species. Based on the ecological information generated in this study, effective management plans can be developed for the indoor house rat populations.

\section{ACKNOWLEDGMENTS}

We are thankful to the Higher Education Commission (HEC) of Pakistan for providing financial support for this work under grant No. 2BMI-489 (Indigenous 5000 Ph.D. fellowship program) and No. 20-1822.

\section{DISCLOSURE STATEMENT}

The authors have no conflict of interest.

\section{REFERENCES}

Aplin, K. P., P. R. Brown, J. Jacob, C. J. Krebs, and G. R. Singleton. 2003. Field methods for rodent studies in Asia and the Indo-Pacific. Canberra: Australian Centre for International Agricultural Research.

Beg, M. A., M. Mushtaq-ul-Hassan, S. Kausar, and A. A. Khan. 1983. Some demographic and reproductive parameters of the house rat population from Faisalabad (Pakistan). Pakistan Journal of Zoology 15: 83-87.

Brooks, J. E., D. W. Walton, U. H. Naing, U. M. M. Tun, and
U. P. T. Htun. 1978. Some observations on reproduction in Rattus rattus (L.) in Rangoon, Burma. Zeitschrift für Säugetierkunde 43: 203-210.

Brooks, J. E., E. Ahmed, and I. Hussain. 1994. Reproductive biology and population structure of Rattus rattus in Rawalpindi, Pakistan. Zeitschrift für Säugetierkunde 59: 209-217.

Byers, K. A., M. J. Lee, D. M. Patrick, and C. G. Himsworth. 2019. Rats about town: A systematic review of rat movement in urban ecosystems. Frontiers in Ecology and Evolution 7: 1-12.

Dowding, J. E., and E. C. Murphy. 1994. Ecology of ship rats (Rattus rattus) in a kauri (Agathis australis) forest in Northland, New Zealand. New Zealand Journal of Ecology18: 19-28.

Duplantier, J. M., J. Catalan, A. Orth, B. Grolleau, and J. B. Davidian. 2003. Systematics of the black rat in Madagascar: consequences for the transmission and distribution of plague. Biological Journal of the Linnaean Society 78: 335-341.

Efford, M. G., B. M. Fitzgerald, B. J. Karl, and P. H. Berben. 2006. Population dynamics of the ship rat Rattus rattus L. in the Orongorongo Valley, New Zealand. New Zealand Journal of Zoology 33: 273-297.

Etougbétché, J., G. Houémènou, H. J. Dossou, S. Badou, P. Gauthier, I. Y. Abdou Karim, V. Nicolas, and G. Dobigny. 2020. Genetic diversity and origins of invasive black rats (Rattus rattus) in Benin, West Africa. Journal of Vertebrate Biology 69: 1-11.

Gomez, M. D., J. Priotto, M. C. Provensal, A. Steinmann, E. Castillo, and J. J. Polop. 2008. A population study of house mice (Mus musculus) inhabiting different habitats in an Argentine urban area. International Biodeterioration and Biodegradation 62: 270-273.

Himsworth, C. G., K. L. Parsons, C. Jardine, and D. M. Patrick. 2013. Rats, cities, people, and pathogens: a systematic review and narrative synthesis of literature regarding the ecology of rat-associated zoonoses in urban centers. Vector Borne and Zoonotic Diseases 13: 349-359.

Jones, H. P., B. R. Tershy, E. S. Zavaleta, D. A. Croll, B. S. Keitt, M. E. Finkelstein, and G. R. Howald. 2008. Severity of the effects of invasive rats on seabirds: A global review. Conservation Biology 22: 16-26.

Khanam, S., and M. Mushtaq. 2021. Farmers' knowledge, attitudes and practices towards rodent pests and their management in rural Pothwar, Pakistan. Pure and Applied Biology 10: 1181-1193.

Khanam, S., M. Mushtaq, A. R. Kayani, M. S. Nadeem, and M. A. Beg. 2017. Small mammal community composition and abundance in rural human habitations of Pothwar, Pakistan. Tropical Ecology 58 (3): 517-525.

King, C. M. 1982. Age structure and reproduction in feral New Zealand populations of the house mouse (Mus musculus) in relation to seedfall of southern beech 
(Nothofagus). New Zealand Journal of Zoology 9: 467-480.

Meerburg, B. G., G. R. Singleton, and H. Leirs. 2009. The year of the Rat ends - time to fight hunger! Pest Management Science 65: 351-352.

Miller, C. J., and T. K. Miller. 1995. Population dynamics and diet of rodents on Rangitoto Island, New Zealand, including the effect of a 1080 poison operation. New Zealand Journal of Ecology 19: 19-27.

Mushtaq-ul-Hassan, M. 1993. Population dynamics, food habits, and economic importance of house rat (Rattus rattus) in villages and farm houses of central Punjab, Pakistan. (Unpublished). Ph.D thesis, Univ. Agriculture, Faisalabad, Pakistan.

Mushtaq, M., A. R. Kayani, M. S. Nadeem, and M. A. Beg. 2014. Distribution pattern of commensal rodents in shops of urban Rawalpindi, Pakistan. Pakistan Journal of Zoology 46: 1585-1589.

Panti-May, J. A., S. H. Betancourt, H. R. Pina, and S. M. Peralta. 2012. Abundance and population parameters of commensal rodents present in rural households in Yucatan, Mexico. International Biodeterioration and Biodegradation 66: 77-81.

Pimentel, D., R. Zuniga, and D. Morrison. 2005. Update on the environmental and economic costs associated with alien-invasive species in the United States. Ecological Economics 52: 273-288.
Rashid, K., and G. Rasul. 2011. Rainfall variability and maize production over the Potohar Plateau of Pakistan. Pakistan Journal of Meteorology 8: 63-74.

Shiels, A. B., C. A. Flores, A. Khamsing, P. D. Krushelnycky, S. M. Mosher, and D. R. Drake. 2013. Dietary niche differentiation among three species of invasive rodents (Rattus rattus, $R$. exulans, Mus musculus). Biological Invasions 15: 1037-1048.

Sridhara, S., and T. R. Krishnamurthy. 1992. Population dynamics of Rattus rattus in poultry and implications for control. Proceedings of the fifteenth Vertebrate Pest Conference: 224-228.

Tariq, A. R. 2004. Hydrologic assessment of small dams in Potohar area: Case study of Jammergal Dam. Pakistan Engineering Congress, 69th Annual Session Proceedings 647: 271-292.

Volkova, V. V., R. Howey, N. J. Savill, and M. E. J. Woolhouse. 2010. Sheep movement networks and the transmission of infectious diseases. PLOS ONE 5: e11185.

Woodall, P. F., and J. D. Skinner. 1989. Seasonality of reproduction in male rock elephant shrews, Elephantulus myurus. Journal of Zoology 217: 203-212.

Wright, S. Y., C. B. Crawford, and J. L. Anderson. 1988. Allocation of reproductive effect in Mus domesticus: response of offspring sex ratio and quality to social density and food availability. Behavioural Ecology and Sociobiology 23: 357-366. 